\title{
Thick Description of the Teacher-student Relationship in the Educational Context of School: Results of an Ethnographic Field Study
}

\author{
Diana Raufelder ${ }^{1}$, William M. Bukowski ${ }^{2}$, Sonja Mohr ${ }^{3}$ \\ ${ }^{1}$ Department of Educational Science and Psychology, AB Methods and Evaluation, Free University Berlin, \\ Berlin, Germany \\ ${ }^{2}$ Interpersonal Relationships and Development Laboratory, Centre for Research in Human Development (CRDH), \\ Concordia University, Québec, Canada \\ ${ }^{3}$ Educational Psychology, Institute of Education, Berlin Institute of Technology (TUB), Berlin, Germany \\ Correspondence: Diana Raufelder, Department of Educational Science and Psychology, AB Methods and \\ Evaluation, Free University Berlin, Habelschwerdter Allee 45, 14195 Berlin, Germany. E-mail: \\ diana.raufelder@fu-berlin.de
}

Received: March 22, 2013 Accepted: April 12, 2013 Available online: May 1, 2013

doi:10.11114/jets.v1i2.108 URL: http://dx.doi.org/10.11114/jets.v1i2.108

\begin{abstract}
Complexities of essential aspects of the teacher-student relationship were identified in a group of German adolescents and their teachers through participant observation. It is already known that the determinants of the teacher-student relationship cannot be simply categorized and analyzed as univariate features. Using Clifford Geertz's concept of "thick description," empirical data were collected during a six-month field study at a secondary school in the south of Germany. Thematic analyses of the extant empirical database identified six sociological principles that constitute fundamental components of the teacher-student relationship: power, dualism, solidarity, productivity, sympathy, and identity. Analyses showed that meaningful ritualized structures limit teachers and students to institutional roles that are incongruent with the general aim of having productive interactions in educational settings. The complexity of educational settings can only be grasped if the teacher-student relationship is understood as an interpersonal process. When reduced to their institutional roles, both teachers and students experienced their relationship and educational settings as unsatisfactory.
\end{abstract}

Keywords: teacher-student relationship, thick description, Clifford Geertz, participant observation, teacher role, student role, school culture, ethnography

\section{Introduction}

Although no one disputes the importance of the quality of the teacher-student relationship for educational processes qualitative research that focuses on a realistic representation of this relationship from the participants' points of view ,including the perceptions and experiences assigned to this relationship as well as its influence on learning, has been infrequent. In the present study, an anthropologically informed approach was used to examine the basic features and processes of the relationships between a group of adolescent students and their teachers. Multiple quantitative studies have demonstrated that characteristics of the school context are important predictors of children's and adolescents' learning and development (Wentzel, 2009; Hascher, 2007; Hüther, 2007, Klem \& Connell, 2004). These quantitative studies show that school is fundamentally a social context and that one's interpersonal experiences in school settings exert powerful influence on the processes of learning and teaching (Hamre \& Pianta, 2006; Vieno, Santinello, Pastore, \& Perkins, 2007; Wentzel, Battle, Russell, \& Looney, 2011; Klem \& Connell, 2004; Birch \& Ladd, 1997, 1998; Krüger, 1994; Evans \& Eder, 1993). Developmental contextualism theory (Lerner, 1991), focuses on the changing relations or "co-actions" (Gottlieb, 1997) between the developing individual and his or her context. Accordingly, the present ethnographic field study adopted an interdisciplinary perspective from the domains of cultural anthropology and educational psychology in order to explore processes within this social context; specifically, constitutional principles and the relevance of teacher-student relationships were studied in a secondary school in a rural area of southern Germany. Using the ethnographic concept of "Thick Description" (Geertz, 1993), six fundamental principles and 
attributes of the teacher-student relationship were examined via an exploration of short meaningful episodes of everyday occurrences. We begin with brief reviews of the theoretical background of teacher-student relationship to better understand its interdependent and complex structure.

\section{Teacher-Student Relationship}

Studies concerning the teacher-student relationship have a long tradition in educational psychology. Models developed in the last century have typically treated the teacher as the primary unit or category of analysis. In research on educational styles, teacher personality and models of anticipation/expectation effects have received extensive attention (Lewin, Lippit, \& White, 1939; Brophy \& Good, 1976; Tausch \& Tausch, 1991), particularly as compared to the attention devoted to the student- and the teacher-student relationship.

In line with developmental contextualism theory (Lerner, 1986, 1991, 1998), Nickel (1981, 1993) has conceptualized the transactional model of the teacher-student relationship. This model underlines the need to focus on the complex processes and dynamics that regulate the teacher-student relationship. The teacher-student relationship is essential to the construct of interest (e.g., Birch \& Ladd, 1996, 1997; Pianta \& Nimitz, 1991), the need for learning support (Pianta, Hamre, \& Stuhlman, 2003; Raufelder \& Mohr, 2011), and has a major impact on students' motivation to learn (Wentzel, 2009; Raufelder, 2007; Raufelder, Jagenow, Drury, \& Hoferichter, 2013; Becker \& Luthar, 2002; Pianta, Hamre, \& Stuhlman, 2003; Stipek, 2004; Wentzel, 2009). Beyond these influences on motivation, learning, academic achievement and performance, teachers act as role models for students and provide a form of non-parental adult support (Raufelder, 2007). In addition, teachers may impart a more general sense of approval or disapproval for the student as a person (Birch \& Ladd, 1996), which can affect students' sense of identity (Alerby \& Hertting, 2007; Birch \& Ladd, 1997, 1998; Jennings \& Greenberg, 2009), as well as their self-perceived competence and efficacy (Haselbeck, 1999, 2007; Bayerwaltes, 2002).

Considering the transactional nature of the teacher-student relationship (Nickel, 1981, 1993), it is not surprising that one of the most important aspects in a teacher's daily functioning is her/his interactions with students (Raufelder, 2007). Interacting with students is not only the most essential component of the experience of being a teacher but it is also its most challenging aspect (Feimann-Nemser \& Remillard, 1996; Ria et al., 2003; Lubbers et al., 2006; Hayer, Scheithauer, \& Petermann, 2005). For that reason, the interpersonal experiences of working with students are a precondition as well as a consequence of being a competent and effective teacher (French, 1997; Horstkemper, 2000; Krumm \& Weiß, 2000). Empirical studies have illustrated the importance of self and identity concerns for teacher development, from initial training to later career issues (Lipka \& Brinthaupt, 1999), as well as social competence (Jennings \& Greenberg, 2009), in order to deal effectively with the challenging interactions and relationships with students in a healthy and successful way. Socially competent teachers are better at developing, and nurturing relationships with their students, managing behavior in their classrooms, serving as behavioral role models for children, regulating their own emotions, and protecting themselves and their students from the "burnout cascade" (Jennings \& Greenberg, 2009).

According to empirical studies and Lerner's developmental contextualism theory (Lerner, 1991, 1998), outlined above, it is not surprising that the determinants of the teacher-student relationship cannot be simply categorized. The dynamic of the interaction between teachers and students is composed of multiple cognitive and emotional patterns and processes that are influenced by the socio-cultural context. The central claim of the transaction model proposed by Nickel (1981) is that social learning experiences and social relationships are predictors of the patterns of interaction between teachers and students. These predictors are also predicated on personality characteristics, role expectations, gender stereotypes, and group norms. Assuming that as individuals both teachers and students actively perceive and interpret reality, these concepts point to the importance of studying the teacher-student interactions and relationships not according to individual features or characteristics but according to the complex processes and dynamics that regulate them.

This general framework (that schools need to be studied as living places for teachers and for students), serves as the conceptual point of departure for the present study interested in the social and cultural forces that regulate the teacher-students interactions and relationships in schools. This approach is based on the cultural anthropological assumption that although some people may exist in the same location, they may differ substantially in how they experience their "living environments" (Roth, 1994; Lofland, 1995; Hitzler \& Honer, 1984). In the present study, human interaction is defined as symbolic (i.e., a cultural aspect), and as a conjunctive realm of experience of the actors. The actors' (i.e., teachers' and students') imparted knowledge (i.e., orientations and theories), as well as their subjective realities, can only be comprehended if the context of the collective interaction patterns is taken into account (Bohnsack, 1997).

Research Aims 
Using an interdisciplinary approach, the present study aimed to examine the teacher-student relationship by using qualitative methods to formulate sociological principles that constitute the fundamental components of the teacher-student relationship in an ethnographic way. The particular method used was "thick description" (Geertz, 1975).Our goal was to create a detailed and realistic representation of the participants' points of view, perceptions, and experiences assigned to the teacher-student relationship. As ethnographic results are generally based on a reconstruction of the participants' experience and their conjunctive realm of experience, hypotheses (though standard in quantitative analyses) contradict this process (Bohnsack, 1997; Becker \& Geer, 1979). Accordingly, an open-ended process was adopted.

\section{Method}

\subsection{Participant Observation: Procedure and Sample}

This six-month participant observation study of teacher-student interactions was conducted in a public secondary school in Germany. Participant observation is a well-established data collection method for qualitative research (Emerson, Fretz, \& Shaw, 2001). Generally, participant observation offers close and intimate familiarity with a given group of individuals (e.g., teachers and students in the school context) and their practices, through intensive involvement with these people in their cultural environment, usually over an extended period of time (Atkinson \& Hammersley, 1994). It allows researchers to reappraise definitions of terms that participants articulated at an earlier time and to observe situations participants or other researchers have previously described. Furthermore, through participant observation the researcher can observe events that informants may be unable or unwilling to share when doing so would be impolitic, impolite, or insensitive (Marshall \& Rossman, 1995). DeWalt and DeWalt described participant observation as a method whose goal is to develop a holistic understanding of the phenomena under study that is as objective and accurate as possible given the limitations of the method (DeWalt \& DeWalt, 2002).

In the present study, participant observation was used to capture the point of view of the teachers and of the students with the goal of a thick description of the teacher-student relationship by formulating sociological principles (Geertz, 1975). Following the ethical standards of participant observation (DeWalt \& DeWalt, 2002; DeWalt, DeWalt, \& Wayland, 1998), both teachers and students were informed and aware that the researchers would participate and observe their daily school life in order to collect data about social relationships in the school context in general. Permission from the school, teachers, parents and students was obtained and all participants were informed that participation was voluntary.

A moderate participant observation procedure was used, in which the researcher maintains a balance between "insider" and "outsider" roles and which allows a good combination of involvement and necessary detachment to remain objective, was used (DeWalt \& DeWalt, 2002; DeWalt, DeWalt, \& Wayland, 1998; Schwartz \& Schwartz, 1955). According to Howell (1972), most participant observation research studies go through four phases: (1) establishing rapport or getting to know the people, (2) immersing oneself in the field, (3) recording data and observations, and (4) analyzing the collected data. Based on these four steps, the present study started with an initiation phase, in which the observer became familiar with the students and teachers she was observing. At the beginning of a new school, the observer was introduced to the teacher staff, all students in $9^{\text {th }}$ grade and their parents. The school was chosen because of its typical character of a public secondary school in a "normal" middle to high SES area in southern Germany. Following an initial week in which the observer took part in each of the three $9^{\text {th }}$ grade classes, a particular $9^{\text {th }}$ grade class was chosen. This class was made up of 11 boys and 16 girls who were very lively in their social interactions with their teachers.

The next four weeks consisted of field immersion that would be a prelude to the actual investigation. During the investigation, the class consisted of 27 students from ages 14 to $16\left(\right.$ Mean $_{\text {age }}=14.7$ years; $\left.S D=.55\right)$. This age group was chosen because in adolescence, girls and boys are searching for orientation and support (from peers or adults) to develop their identity and a constructive selfhood (Harter, 1999; Raufelder, 2007; Fend, 1997). Furthermore, this age group was interesting due to the fact that students' motivation begins to decline rapidly after the transition to secondary school and continuing through the first three years of high school (Harter, 1996), reaching its nadir in $9^{\text {th }}$ grade (Eccles, Wifield, \& Schiefele, 1998; Watt, 2004; Zusho \& Pintrich, 2001).

The actual investigation consisted of two phases. Initially, the $9^{\text {th }}$ grade class was accompanied and observed for three months. The purpose of this phase was to grasp the students' points of view concerning their relationships and interactions with all of their teachers $(\mathrm{N}=12)$. During the second three-month phase the teacher of this $9^{\text {th }}$ 
grade class (Mr. Hofstätter ${ }^{1}$ ) was accompanied and observed. Mr. Hofstätter had been working in the school for almost 30 years teaching mathematics and sports.

The observer sat at the sideline of the classroom in order to have a comprehensive view of the interaction processes within the class. Because both the teachers and students were initially insecure about the observer's practice of keeping careful field notes about the classroom activities, only short headwords, quotations and brief notes were made during class time (e.g., as outlined by Harrington, 2003). During the afternoons following these observations, these notes were comprehensively analyzed and detailed memory protocols were constructed. So as to minimize distortions in subsequent analyses of the data, no motives for actions and interactions were assigned in the protocols. In addition to these observation protocols, open-ended interviews that lasted from 30 to 90 minutes were conducted with students and teachers to collect first-hand data and to perform data triangulation as a form of cross-checking information (Douglas, 1976; Lincoln \& Guba, 1985). This triangulation procedure was used to minimize the observer-expectancy effect (Douglas \& Johnson, 1977). Finally, after six months of observation, data analyses were conducted.

\subsection{Qualitative Analyses}

While quantitative studies may offer us an overall idea of the typical experience (i.e., girls tend to perceive the teacher-student relationship more positively than boys, on average), qualitative approaches focus on the individual's point of view, feelings, thoughts, interpretations, and perceptions as well as on social reality (Becker, 1996). In these ways qualitative research allows a deeper understanding of the personal and social experiences of people (Smith \& Osborn, 2003). Currently, qualitative studies on the teacher-student relationship are rare.

The taped and transcribed interviews, as well as the observation protocols collected during the participant observation, were analyzed with thematic analyses (Braun \& Clark, 2006). This form of analysis uses methods of constant comparison to ensure that emergent themes (principles) remained grounded in the data. Our objective was to analyze expressive themes in order to formulate sociological principles that constitute the fundamental components of teacher-student relationship. The observer was assisted by two other researchers with experience in qualitative design and analysis (investigator triangulation). In the present analysis, the reasoning was mainly inductive, such that we did not have any pre-existing frame in which we aimed to fit the data. When dealing with unexplored research topics, such as the constitutional principles and relevance of the teacher-student relationship, and when one is using a complex multidisciplinary perspective that includes concepts from diverse domains such as cultural anthropology and educational psychology, the use of an inductive approach is particularly advantageous.

According to Braun and Clark (2006), five different phases of thematic analysis were followed. In the first phase, the researchers familiarized themselves with the data by transcribing the interviews and by reading and rereading them. The second phase is characterized by generating initial codes that cover the entire set of data by going through the transcripts, paragraph by paragraph. In the next phase, potential overarching themes were identified. In the fourth phase, the chosen themes were reviewed and refined. The fifth phase aimed to define and name these identified themes. A final step in the thick description process was the summarizing of the observed themes into six sociological principles.

Data analysis was conducted by hand. An iterative analytic process that relied on methods of constant comparison with repeated scrutinizing of transcripts was used to determine the themes emerging from the data. Analytic themes were continually identified until the researchers agreed that there were no further themes to be identified. The identified themes were used to formulate sociological principles that appeared to comprise the fundamental components of teacher-student relationship.

\subsection{The "Thick Description" of Clifford Geertz}

The overall goal of the analyses was to create a thick description of the teacher-student relationship. Thick description is the well-known semiotic concept developed by Geertz (Geertz, 1975, 1983, 1993, 2000). Its essential premise is that, "[humans are] animals suspended in webs of significance [they themselves have] spun" (Geertz, 1973, p. 5). Geertz conceives of these webs as "culture." According to the conceptualization, culture includes public codes that bring "phenomenalistic" aspects of human interaction to be understood as certain signals, (e.g., body movements are interpreted as representing a certain indication in a specific context) (Geertz, 1973, p. 6). Whereas a "thin description" is concerned with actual practices, the goal of a "thick description" is to identify the "interpretive" or "meaningful structure" of these practices (Geertz, 1973, p. 7). The aim of

\footnotetext{
${ }^{1}$ All names are pseudonyms
} 
analyses of cultures is not to generate rules but is instead to search for and interpret certain meanings (Geertz, 1983). Ethnographers can only interpret meaning when they are aware of the "public code." Accordingly, the aim of the analysis is to elaborate basic meaningful structures and to gain access to the cultural components that serve as the basis for the symbolic actions of the observed persons. The project was guided by Geertz's claim that, "doing ethnography is like trying to read (in the sense of "construct a reading of") a manuscript - foreign, faded, full of ellipses, incoherencies, suspicious emendations, and tendentious commentaries, but written not in conventionalized graphs of sound but in transient examples of shaped behavior" (Geertz, 1973, p. 10). The goal of the observational processes was to collect information about social behaviors, especially at a microscopic level, and to use interpretive strategies to capture their meaning. The basic units of analysis were descriptions of everyday situations or interaction patterns, so-called symbolic behaviors, in which the important aspects and dimensions of human life emerge. The main goal of a thick description is to formulate sociological principles, which together describe the entity of a cultural unit (e.g., the teacher-student relationship in the school context) (Geertz, 1973).

\section{Results}

The extant empirical literature was used to guide the choice of six sociological principles that constitute the fundamental components of teacher-student relationship. These are power, dualism, solidarity, productivity, sympathy, and identity. These principles are not considered as unitary or independent concepts but rather as a complex network of interdependent factors derived from patterns of interaction. In the following paragraphs, these six principles are summarized, and select excerpts from observation sequences and the interviews are used to illustrate the participants' account for each principle. A detailed "thick description" would go beyond the scope of this article. Analyses presented are based on coding of the whole sample with excellent inter-rater agreement $(\kappa \geqslant .83)$. All names of teachers, students and the school are pseudonyms.

\section{Constitutional Principles of the Teacher-Student Relationship}

The role of the student is often "simulated" in a reductive role-oriented process in research on school context (Hornstein, 1990). A more comprehensive view considers the student role within the frame of their whole personality and "student-being" (Böhnisch, 1996). "Being" has been described as the actual mental state of someone that affects the whole personality, even though the person possesses a certain role in certain situations (e.g., being in the role of a student, a teacher, a social worker, a woman, or other connected roles) (Nohl, 1933, 1957; Böhnisch, 1996). In the ethnographic description of the teacher-student relationship, the restrictiveness of these role patterns was corroborated for teachers and students. Whereas the principles of power, solidarity, dualism, and productivity are interconnected and function to enforce particular role patterns, the principle of sympathy has the ability to undermine these patterns through affecting the "being" of the teachers and students. The principle of identity serves another function. It is through identity that idealized conceptions that teachers and students hold, both of themselves and of each other, become apparent. Consistent with the conceptual divergence between the formal definition of roles and the concept of being, the present observations demonstrate that perceptions of the self and of the other can differ substantially from more explicit institutional definitions of what it is to be a teacher or a student.

In the sections that follow, the observations related to each of these principles are discussed. This discussion takes a thick-description approach to the explication of how these principles arise in the dynamics of the teacher-student relationship. Our goal was to identify the meaningful structures related these principles within this interpersonal context.

\subsection{Power}

Max Weber defined power as "the probability that one actor in a social relationship will be in a position to carry out his will despite resistance, regardless of the basis on which this probability rests" (Weber, 1921/1980, p.20).

It is often assumed that a fundamental power-related conflict of interest exists between teachers and students (Krüger, 1994): students strive to finish class with the least amount of effort whereas teachers see it as their professional duty to attend to the demands of the curriculum and to motivate the students to devote themselves to their work. In class, some students often play tricks and interrupt the teacher and the other students by making jokes, adding extraneous comments or engaging in forms of entertainment. These actions are effective ways of reducing the amount of class time devoted to learning. It was observed that the atmosphere in class was determined by those students who tried to disturb the effectiveness of controlled instructions. By contrast, the teachers focused only on meeting as many of the formal requirements of the curriculum as possible without wasting time. In doing so, the teachers had no choice but to cope with the presence of inattentive and unmotivated students. This power-related conflict derives from the teacher's desire to cover as much subject 
matter as possible, while the students' actions result in the exact opposite effect. In such situations of conflict, the central issue is how the distribution of power is used to enforce a certain interest. The involved parties (i.e., teachers and students) make use of different opportunities in exerting the influence of their own power. Teachers are in an authority position because they have the power of the school behind them. Typically, teachers have the power to control their instruction and make use of different penalty opportunities.

During the chemistry lesson, Mr. Behringer took away Boris's Discman. Although six other students were using their Discmans, only Boris was reprimanded and had his name entered into the class book. When Boris complained about what he thought was unfair treatment, Mr. Behringer interrupted him and said: "I do not discuss these matters with you!"

Boris answered: "But you have to!"

But from Mr. Behringer's point of view, he was not required to do anything. Instead of discussing what had happened with Boris, he became loud, enraged, shouted and took away the Discman. Boris stayed calm.

Observation Sequence 11/18/2002

Six of seven students had headsets on, but only one of them (Boris) received a class book entry for this. We can not reconstruct Mr. Behringer's motives, but the way in which he handled the situation is an indication of his power. It is possible for him to judge students' behavior differently and determine who will receive penalizing. He clarified this fact with the sentence, "I do not discuss these matters with you!" Boris questioned Mr. Behringer's power by answering "But you have to!" A demonstration of Mr. Behringer's power follows with his high degree of emotionality: he shouts senseless sentences at Boris. To demonstrate the degree of power, he removed Boris' Discman for an indefinite period of time.

Although Boris said afterwards that he was very angry and upset, he remained calm and accepted the power structure during class. In other words, while the teachers can show their emotions without consequence, students cannot do so. With restricted penalty opportunities, the power that students do hold is based on their numbers and as such, a student rebellion against the authority of a teacher seems to have a liberating effect upon them.

During German lessons, year nine students were very boisterous. If the assistant teacher turns to the blackboard to write something on it, some boys started to shout "pit stain" or "giraffe". They shouted "pit stain", because you could see perspiration stains on the shirt of the assistant teacher and "giraffe", because some students thought that Mrs. Long looked like a giraffe. One student actually made up a song entitled "pit stain", which three or four other boys started to sing quietly, but could be heard in every corner of the room. Then, a student by the name of Deria was leaving the classroom to go to the bathroom, she stuck her tongue out at Mrs. Long, who was not able to see this. The students who noticed this started laughing. Mrs. Long tried to quiet them through admonitions and school punishments, but was not successful. The students were getting louder and louder. If somebody gave a right answer to the questions of Mrs. Long, five or six boys would start to applaud. The disruptions continued throughout the lesson.

Observation Sequence 09/10/2002

The limitations of teachers' powers can be seen in this sequence from the German lesson of Mrs. Long and the students' disturbing behavior. Although Mrs. Long doled out school punishments (e.g., asking for silence, having one's name entered in the book etc.), the disruptions continued. Some boys, in fact, resorted to bullying the teacher verbally, broaching the issue of the stains on her clothing and calling her names (e.g., "giraffe"). The "active" boys (i.e., those that call the teacher names) are supported by the "passive" students (i.e., those that do not call the teacher names), simply by their laughter. As Mrs. Long became more helpless, the power of the students increased. By sticking out her tongue, Deria, who was normally a calm and inconspicuous student, showed that the students know about their power and feel safe in the company of many peers.

Loser and Terhart (1994) explain this type of behavior as "secondary moderated" or "secondary destructive" achievement, a result of the identity-threatened educational setting. In other words, students have been reduced to their role; teachers ignore the whole "student-being" (Böhnisch, 1996), which students can perceive as identity-threatened, and they then react with so-called secondary achievement (Loser \& Terhart, 1994). For that reason, both students and teachers assume that a fundamental conflict permeates their every-day contexts.

\subsection{Solidarity}

The principle of solidarity is defined as a union of interests, purposes, or sympathies among members of a group (The American Heritage Dictionary of the English Language, 2000). During the six months of field observation, 
solidarity appeared to be a kind of weapon with its primary use to defend oneself against external interferences. Accordingly, students show solidarity with each other if teachers were to turn against one or several students. The same reactions were observed in teachers' behaviors.

Micha got a class book entry from Mr. Behringer, because of "saying goodbye too intensely." When Mr. Hofstätter, the class teacher, read this entry, he asked Micha what had happened. Micha said that the whole situation was very harmless and he just said goodbye three times and Mr. Hofstätter answered: "When Mr. Behringer feels disrupted, he is correct".

Observation Sequence 10/18/2002

Based on the teachers' solidarity, Mr. Hofstätter took the side of Mr. Behringer even though he had not witnessed the event that led to the class book entry. Mr. Behringer's feeling of disruption is enough to legitimize the class book entry. The teacher's word counts more than that of the students and other information is not required. In spite of the relative harmlessness of the infraction committed by the student ("saying good bye too intensely") the claim of the colleague was enough for another teacher to take his point of view.

At a parent-teacher conference, the classroom teacher went so far as to appeal to parents' for their understanding and support in "fighting" against his students. By using the term "fight," the ritualized conflict between teachers and students became apparent.

A class conference was called just two weeks after the beginning of the school year because of multiple problems and disruptions in the grade nine classes. The teachers collectively talked about how to curb the students' disruptive behavior.

Observation Sequence 02/10/2002

As soon as possible, the teachers of Class $9 \mathrm{~b}$ met to ensure their solidarity. Because the class was a bit difficult (i.e., loud and unfocused), they thought about common teaching strategies to deal with the disruptions caused by students. Teachers followed the principle of solidarity to build a common front against the students. They even tried to enlist the teacher from the parent-teacher conference to support them in their "fight" against the students. The students' solidarity was often expressed via teamwork.

The test in music class was based on teamwork. Only two students were able to answer the test questions of Mr. Guppi. Therefore, throughout the test, solutions were whispered and small papers with the answers were exchanged. Essentially, nobody learned from this experience. Boris said: "Why should we learn, it has no effect."

At the end of the test Mr. Guppi forgot to collect Deria's test. During the break after the test, Beatrice (one of the two students who was able to answer the test questions) completed Deria's test in the bathroom. After this break, Class 9 had another art class with Mr. Guppi. Seda, another student, asked Mr. Guppi to copy a paper for her and Mr. Guppi left the room to copy it. While Mr. Guppi was absent, the students opened his school bag where he was keeping the tests. They took Deria's test and closed the suitcase. When Mr. Guppi came back, everyone was highly concentrated.

Observation Sequence 12/02/2002

The students were not prepared for a test in music class since they believed that they would find a solution together via teamwork. They helped each other by whispering and exchanging information. In the case of Deria, the students even tricked Mr. Guppi. Seda asked for a copy of an exam she did not actually need, simply to get Mr. Guppi out of the classroom. Although Beatrice is a very religious and hard-working student, she took the risk of getting caught red-handed and filled in Deria's test in the bathroom. They helped each other out as much they could.

Solidarity was not a constant condition. It was exhibited only when it was needed as a strategy to deal effectively with the action of the opposing group. In the absence of challenges from the students, the solidarity of the teachers decreased; when challenges from the teacher decreased, so did the solidarity of the students.

Power and solidarity are inter-connected; they form a coherent process in which solidarity stabilises and amplifies power. This coherence is manifested in the principle of dualism.

\subsection{Dualism}

The dynamic interchange between power and solidarity results in the principle of dualism. In the present study, dualism refers to the intersection between two "scopes of being" (Böhnisch, 1996), one for the students and one for the teachers. In the midst of the dynamics of the dual system, teachers and students cannot meet as 
independent beings because they are caught up in a polar struggle over power. Because the dualism is pervasive within the school environment, there is no space for the personal scope of being a teachers or a student. The principle of dualism became particularly apparent because the researcher failed to be a part of the culture without attracting attention (eg., Harrington, 2003; Crowley, 2007). At any time the observer was perceived to be a part of one group or the other. As a consequence, distrust was shown to her by both of the groups. Due to the principle of dualism, the observer was unable to be seen as representing a neutral position, although both teachers and students initially knew about the observer's research interest. The more time the observer experienced with the students, the more the teachers saw her in this role and treated her like a student. The mistrust and the insecurity of some teachers regarding the observer's presence became so high that they called upon the staff council to discuss with her some "fundamental things" about the school as Mr. Fuchs, the principal, stated.

I was invited to the staff council session. There were six teachers and myself. Mr. Schafer said, "This is not the inquisition. We just want to talk with you because there are some problems. Some colleagues said that you have been unfriendly and you have been drinking water during class time." Also they wanted to know why I was conducting my study in that particular classroom. They suggested that I search for another school and classroom. They even told me that they had a good contact with another school nearby where arrangements could be made for me. They also wanted to know what kind of results I had, what I had written down, what I observed and why I needed personal contact with the students especially since this contact would invalidate my findings. I was told to keep more distance so as to protect myself from the possibility of being used by the students for their own strategic purposes. At this meeting I was informed that the teaching assistants of Mrs. Long and Mrs. Biedermann would no longer allow me to take part in their lessons. The staff council told me to meet with them again ten days. At this second meeting I was asked if I wanted to stay in the particular class I had been studying. They also wanted to know if I would change into another class or school to attain my data. At this meeting they demanded that I produce an official letter from my professor and a full description of the purposes of my dissertation study.

Observation Sequence 10/21/2002

The grievances that the teachers had about the observer and her presence and their view of the observer as a member of the "other side" (i.e., as a student), derived from the principles of dualism and solidarity. Drinking water during a lesson is not allowed for students, although it is for teachers. A teacher would never criticize another teacher or an adult for drinking water during the lessons. They identified the observer as a student, because dualism forbids any alternatives: one is either a teacher or a student - there is no neutral zone in between. Because the observer had spent a lot of time with the students by talking with them and having a close relationship with them, the teachers thought the observer was a part of the other community.

The mistrust and insecurity of the teachers were especially obvious in the second part of this observation sequence. The offer to help the observer to go to another school to conduct the field research was intended to get rid of both the observer and, in doing so, to relieve their insecurity. Also, the questions about what the researcher was observing and recording shows their insecurity towards the observer and her work. It is possible that the question about her findings and her notes are due to the teachers' fear that the observer could obscure or distort something important for them (e.g., the quality of their work as teachers, or the students' views of them as teachers). The warning that personal contact with the students would falsify the findings and that the students may use the researcher for their own ulterior purposes is especially interesting. With these words, they challenge the observer's status as a scientist-researcher. Following the rules of the dualism, science is part of the adult world, the teacher-side. Seeing the observer as on the other side (i.e., the student-side), how could the researcher be like an adult and being one of them? How could the researcher possibly be a scientist? They told the observer how to run her study because they are the teachers - it is their task to control and direct the students and, from their point of view, the researcher was a student. The observer learned from this meeting that her behavior did not conform to that of the teachers. Mistrust and alienation were the result. The researcher had personal contact with the students, talked with them directly, and shared her knowledge with them. In other words, she was willing to see their "student-being" (Böhnisch, 1996) and did not reduce them to their "student-role". That is not the way most teachers usually treat their students.

This pattern seems to be a common form of group-dynamics in social contexts. When an individual from outside the normal group composition is perceived to threaten the inner solidarity of the group, the group's solidarity becomes even stronger. The two teaching assistants, who were no longer willing to accept the observer in their lessons, tried to protect the entire group of teachers by identifying the observer as an external agent. Lacking 
solidarity with the teachers and lacking distance from the students led to the logical assumption that the researcher should leave the teacher-group. Because the researcher was not willing to leave the class and the school, an external letter was required from her professor in order to legitimize and clarify her liminal position (i.e., as being part of neither group). Finally, the committee gave the researcher ten days to think about her decision and invited her to another meeting where every teacher was invited to ask the researcher any questions they might have.

The teachers wanted to know what results I had and what exactly I was writing down. Furthermore, they again asked why it was necessary to have personal contact with the students, which they believed would falsify my results. They gave me the advice to keep more distance, otherwise the students would take advantage of me. I managed to convince them about my empirical method, explained my dissertation design and talked with them in a constructive manner. After a while Mrs. Zeits said: "It looks as if you were on the side of the students and are against the teachers. That led to an outcry in the teachers room." Moreover, she asks me if it would not be better to choose one side. From her point of view, it is difficult or even impossible to hold both sides of view (i.e., that of students and of teachers simultaneously). Finally, she predicts that I will have problems with the students as well when I change focus and take the teacher's point of view in January for three months.

Observation Sequence 11/01/2002

The sequence shows that the teachers were still full of mistrust and insecurity concerning the researcher. This fact is not specific to a few teachers, instead they were all unsure about her research and her position. Mrs. Zeits had chosen the words "outcry in the teachers' room", which indicates the intensity of the situation. She mentioned the impossibility to investigate both sides, which marks the extent of the dualism. This reflects her belief that the gap between the two "beings" is so large so that it would not be possible to grasp both sides. She was certain of this because she is a teacher, and for her there is no need to understand the other side. This moment shows that a huge gap separates teachers and students, even though they can be in contact while in their "teacher-role" and "student-role".

A similar process was seen in the second part of the participant observation, when the researcher focused on the teachers' daily life and their point of view. In these observations, the students showed similar insecurities.

I met Boris on the stairs. He asked me about my opinion concerning a situation with Mr. Hofstätter, who left the classroom the week before 30 minutes before the end of class without saying a word to the students. Although all of the students addressed me using the informal "you" ( $d u$ in German) during my time with them in class, Boris addressed me formally (Sie in German) outside of the classroom.

Observation Sequence 02/14/2003

This usage is an indication of dualism as well: Boris reassigned the observer to the group of the teachers by using the formal rules concerning teachers, although he used the informal "you" during the three months before, when the researcher took part in the students' daily lives.

The sequences identified in thick description revealed that teachers and students are only coexisting and disclaiming/avoiding contact. According to the concepts proposed by Böhnisch (1996), each group is living in its own "scope of being." They interact according to their institutional roles. Defence, mistrust, and skepticism affect the role identities. They maintain a negative connotation in matters concerning their counterpart. Consequently, the development of effective cooperation and educational companionship is almost impossible.

\subsection{Productiveness}

The principle of dualism is also interconnected with the principle of productiveness. Productiveness refers to the processes related to the explicit purposes of schools, specifically to impart pragmatic social and technical knowledge. Teachers are the people in charge of the process and students are regarded as the "consumers," a role they experience to be aversive. Traditionally, the goal of school-based education has been perceived to be the transmission and acquisition of standardized knowledge and learning strategies. In contrast to this traditional view, the results of the present study indicate that interest, motivation to learn, and individuality are currently to a large extent disregarded. These basics aspects of "being" (Böhnisch, 1996) are ascribed with little significance. This educational style results in teaching and learning processes, whose achievement of objectives can be troublesome and whose productivity is low. Productivity also stands before interest.

Some of the girls are talking about the elections for the Bundestag (the German federal assembly), which were the day before. During religion class, Thomas asked Mrs. Hepperle to talk about the election. Mrs Hepperle refused. She said she would not speak about the election. A girl then asks her 
how to explain how politics influence the school. She states that the Federal Chancellor Schröder didn't want to take part on PISA-studies for teachers. "That is unfair," the girl says. "Teachers are also responsible for the bad results of Germany in PISA". Other students agree with her. Mrs Hepperle blocks the upcoming discussion and goes back to the day's lesson plan. When another girl began to say something about PISA and Mrs Hepperle stopped her as well.

Observation Sequence 09/23/2002

Mrs Hepperle interrupted the students who wanted to talk about the elections for the Bundestag and the PISA-study three times. When a student explicitly asked to talk about this, she shrugged him off. The students' interest in societal and political contemporary issues (eg., the elections and the PISA-study) was ignored by Mrs Hepperle because it is not part of the curriculum. Productivity comes before personal interests. This approach is contrary to the established concepts of what educational settings should provide, for example, by Rousseau, Pestalozzi, Goethe, Humboldt and even the modern approaches of neurobiological learning studies (i.e., Jenson, 1998, 2000; Ittel \& Raufelder, 2008). There is no place for students' interests in school, not even when they explicitly refer to them at a relevant moment for the society as a whole. Even though the students want to talk about the issue of the PISA assessment, a topic that is of concern to teachers and students, no exception is allowed. In this case, not only were interests and learning-related motivations ignored, but Mrs Hepperle also passed up the opportunity to initiate a dialogue between teachers and students about their own situation and their relationship to each other within the school context. She failed to take advantage of this important opportunity for interaction between teachers and students on the level of "being."

Because teachers understand themselves as leaders of productivity, the role of student has to be one of a consumer. They learn this role from the first day of school.

Mrs Hepperle, the teacher for religion class, asks the students what they think should be on the next test. The students look at each other and are totally silent. After a while, Marcus, one of the students, says: "Mrs Hepperle, just tell us what we have to learn."

Observation Sequence 11/11/2002

This observation sequence shows that students are too overwhelmed to make decisions for themselves. Their helplessness is expressed by their silence. Mrs Hepperle has chosen an unusual way of teaching: normally teachers instruct students on what to do on what they have to learn for the next test. The students felt helpless when given the freedom to choose the test material, illustrated by the fact that Marcus explicitly demanded for the usual way. You could interpret what has happened as, "we don't want to think about what to learn, we are not used to doing so... Just do it, what everyone always does: tell us, what we should do!"

Also Mr. Hofstätter confirms the students' stance over their roles in the learning process:

In the 5th grade, Mr. Hofstätter instructs and supports the students more than in higher class. He tells me: "Yes, they wanted to be instructed. They want me to tell them what they should do. If we plan a trip, for example, I always ask the students where they want to go. Finally, I always have to decide where we will go, because they couldn't decide by themselves. That is the same reason why I think that group work and free work is a limited possibility."

Observation Sequence 02/18/2002

Mr. Hofstätter confirms the role patterns of both the teachers and the students. Teachers are perceived to be productivity leaders and students are the consumers. Students have fully accepted this role, so that they expect to be instructed on what to do by the teachers. In turn, the teachers react with the expected behavior, which inhibits the possibility of a creative cooperation. This process was amplified by the principles of power, solidarity and dualism. All dimensions of daily school life are dominated by this duality: teachers on the one side and students on the other. Even during the learning process (i.e., productivity) they do not work together. The tasks are clearly distributed: Teachers produce class instructions and students consume it. Teachers are the ones responsible for the incomplete knowledge of the students. This duality is illustrated in the short interview sequence with Micha:

\section{I: Are there subjects you don't like?}

Micha: Yes, English.

\section{I: Why?}

Micha: Because until now we only had rigorous teachers who were stupid. This is also the reason why I am not good in English, because we only had stupid teachers who weren't able to teach, so that I learned nothing. 
Interview Sequence 10/14/2002

The consequence of this learning process for productivity is that teachers and students are very much fixed in their internalized institutional roles. Individual needs, interests and motivations cannot be considered, because the production must go on. There is no chance to develop the learning and teaching process together. The relationship between teachers and students is reduced in a "communicative way" (Bohnsack, 2004), which is influenced by exteriority and coercion. Comparing the educational setting to an industrial productivity process clarifies the lack of "being" in the teacher-student relationship. Although it is the public task to educate students in their whole being, education in school backs away from this broader goal in favour of a narrower approach oriented toward instrumental productivity, rather than on the development of the whole individual.

\subsection{Sympathy}

In some exceptional cases, a "real" educational relationship was constituted (Nohl, 1933/1957) in the sense that sympathy succeeded in overcoming the rigid social context and the described dualism between teachers and students. These moments of sympathy typically included instances of empathy on the part of a teacher. In the course of these instances of sympathy, teachers and students became "authentic" counterparts, and motivation and enjoyment were developed, which affected learning positively. This was, for example, reported in an interview with Fabienne:

"I: Fine, but what do you expect from teachers?

Fabienne: I want them to be like Mr. Pilari, you learn something and they are also like buddies.

I: Do you miss that in your teachers' behavior?

Fabienne: Yes, they should be more like Mr. Pilari. He was so kind and I learned so much and had so much fun."

Interview Sequence 09/20/2002

Sympathy is closely connected to productivity. This connection is apparent in students' statements:

"I: Do you have a favorite subject?

Micha: Yes, math.

I: Why?

Micha: It's fun.

I: And which role does the teacher play?

Micha: A big role. If I have a teacher I don't like, I don't cooperate very well, and I don't have much fun."

Interview Sequence 10/14/2002

Micha indicates how sympathy increases productivity from his point of view. If he likes a teacher, he works more actively and has more fun. The sympathy for a teacher is transferred to the learning process. But the students also understand the distinction between sympathy and the professional quality of a teacher. If a teacher is good in a professional way, it does not matter if they like him or not or if their sympathy is based on the professional qualities. This distinction between sympathy and professional qualities is demonstrated in the following interview sequence:

\section{"I: How is Mr. Ulman?}

Frank: He is good. He is one of my favorite teachers...

\section{I: Why is the class so silent during his lessons? He rarely gives school punishment?}

Frank: ... he gives punishment. Sometimes he gives school punishments. Last year he made some of us stressed, but I think most of us like him because we don't want to loose him. Last year he was so angry with us and he said that he didn't want to teach us next year. I guess, nobody wants to get another teacher for physics because he is the best one in this subject, he explains so well. Some of us had another teacher last year, Mrs Grei, and she was a catastrophe. You don’t learn anything during her lessons.”

Interview Sequence 09/23/2002

The sympathy Frank has for Mr. Ulman is built on his quality as a productivity leader ("because he is the best 
one for this subject") and for that reason "we don't want to lose him". Students particularly appreciate his ability to explain the subject well. In this case students make an effort to have a calm and productive learning atmosphere, because they know about the quality of Mr. Ulman in his professional role.

There exists a close relationship between sympathy and the learning process (i.e., productivity) for teachers as well, as the following short observation sequence shows.

With the GK-Sport class, Mr. Hofstätter has created an athletic program to promote muscle development. He says it is fun for him to work with this group, even though the students in the group are not great athletes. But the students in the group work well. "They are sympathetic and motivated".

Observation Sequence 02/04/2003

Mr. Hofstätter had fun despite the fact that "they are not great athletes." He appreciated their motivation and their engagement. He liked them and he had fun. The interdependency between sympathy and productivity is accompanied by positive affect and engagement. The principle of sympathy supports the process of productivity in an enriching way. The restricted institutionalized roles of teachers and students can be broken open by aspects of sympathy.

\subsection{Identity}

The principle of sympathy is directly connected to the last principle,identity. Both students and teachers have an individual idea of how a "good" teacher and a "good" student must be. Accordingly, the observed sequences were particularly interesting, in which students revealed that they expect teachers to satisfy their needs in terms of "being" and in terms of their role were particularly interesting.

"I: What do you expect from teachers?

Deria: That they not only come in, start teaching, have us write things down and so $\cdots$ I mean, they should be more than an educator: they should be a human being...”

Interview Sequence 09/23/2002

In contrast, teachers typically have contact with students at the role-level. Though there are opportunities to interact at the being-level, such as on class trips. Mr. Hofstätter depicted a concrete example:

"I totally changed my mind in terms of some of my students. On the other hand there are students for whom I would have put my hand into the fire, and then they totally disappointed me. But it's safe to say that class trips always have a positive impact on the class, and it's a positive experience for students to get to know their teacher in laid-back situations. "Oh, my teacher is not that strict"..."

Observation Sequence 01/31/2003

During a typical school day there is not enough time or space for teachers and students to meet each other on the "being-level" as human beings. Both students and teachers alike experiences substantial psychological strain in these situations with ritualized, rigid role patterns. As a consequence, they are left alone and pit themselves against each other. It is unfortunate that they cannot see alternatives in such social situations. As a result, being a student or being a teacher has become associated with a permanent fight, and the state of "burn-out" occurs more frequently for teachers than for other professions (Hakanen, Bakker, \& Schaufeli, 2006; Rudow, 1999; Travers \& Cooper, 1996; Schaarschmidt, 2005).

\section{Discussion}

The six principles that were assessed in the analysis of the empirical data illustrate the interwoven dimensions and dynamics of the observed teacher-student relationship. While the principles of power, solidarity, dualism and productivity are interdependent, the principles of sympathy and identity were able to overcome the rigid social context manifested in the first four principles. A "real" educational relationship was constituted (Nohl, 1933/1957) at instances where sympathy and identity succeeded in overcoming the role-level of both students and teachers, and was accompanied by positive emotions, such as enjoyment, interest and inspiration. They are the basis for both teachers' and students' successful educational development. In the daily routine of school, these instances appear infrequently and are the exception. In fact, the institutional role identities (Böhnisch, 1996) of being a teacher or student are affected by power and defense. Consequently, a loose, constructive, and interactive cooperation is almost impossible. The conditions in school determine the structure of the teacher-student relationships in a way that leaves little room to develop a sustainable, human (being-level), and pedagogical (role-level) basis. Successful teaching and learning processes can only be accomplished if they are mutual. In the present study a terrifying and unemotional image of education was discovered, which is 
incongruent with the aims and ideals of education, historically and traditionally.

Personal and being-related dimensions were hidden because they were not needed for the identity role of teachers and students. The role and "being" (Böhnisch, 1996) for teachers and for students are not balanced. This situation creates discomfort for both groups. The following sequence shows, in a very symbolic way (see Geertz, 1976), what happens when teachers and students overcome this separation.

Suddenly it starts to rain hard. The windows rattle and the wind comes through every crack. The rain crackles loudly against the windows and the students become totally silent. Mr. Hofstätter says: "Don't be afraid. I am with you," and the students roar with laughter.

Observation Sequence 01/28/2003

Why did the students laugh? According to Geertz, it is a cultural symbol, which can only be understood if you know the cultural code. The students roared with laughter because Mr. Hofstätter caricatures his own teacher-role. He breaks the rules, which are normally organized according to the principles of power, solidarity, dualism and productivity. Against the rules he appears as a protector, like a "clucking hen, who protects her chicks." He moved into a protective and nurturing role rather than a role aimed at productivity. The students were fully aware that he couldn't protect them against the forces of nature. That was one reason for their laughter: he was making a bit of a joke about himself. But there is another reason: they laugh because it is a close moment of personal contact and of shared of affect between Mr. Hofstätter and the class. He explicitly talks about their relationship, but in an unproblematic way: he makes his own role laughable and in this moment his essential being emerges and merges with theirs. It was a moment of common personhood.

Unfortunately, as the empirical data have shown, the integration of the "entireness of life" in school culture (Loser \& Terhart, 1994) rarely happened By using and establishing programs in schools that focus on socio-emotional aspects of learning and enhance social competence (e.g., GLK Hinsch \& Pfingsten, 2007; SOKO Bornhoff \& Bornhoff, 2007), the environment of schools can be positively affected, and teachers and students maytake notice of each other, turn to one another and meet each other on a level of a "real" educational relationship (Nohl, 1933/1957). Teachers and schools are often so focused on academic achievement that they overlook a key tool (Dressman, 2006), specifically the "being-based" relationship that promotes the emotional health of students and teachers. After reading, writing, 'rithmetic, the fourth ' $R$ ' should be relationship (Bukowski, Laursen, \& Hoza, 2010; Bukowski, Newcomb \& Hartup, 1996). Indeed, it has been claimed that all learning occurs in within a relational context (French, 1997). The results have shown that there are close associations between the teacher-student relationships and the learning process, including aspects of motivation, interest and school well-being. Education is (once again) perceived as a process, in which individuals are learning and developing necessary skills to achieve success in cooperation, to comprehend and critically analyze their life's context, and to develop constructive selfhood.

\section{Limitations, Strength and Future Directions}

As with all research, the findings of the present study should be interpreted in light of a number of limitations. First, the small sample size in this study, which is common to qualitative research methods in general, limits the generalizability of the findings, and therefore, our results need to be interpreted with caution. Nevertheless, through the use of a lengthy participant observation process and through the application of data and investigator triangulation procedures, we aimed to achieve theoretical saturation of the topic of interest (Taylor \& Bogdan, 1984; Morse, 1995). Additionally, it should be noted that observations about a group of people are never going to provide a full description (Peshkin, 1993; Attkinson \& Hammersley, 1994). A second limitation is that the observer first participated in the daily life of the group of students, which might have irritated some teachers. In contrast, when the observer afterwards followed Mr. Hofstätter through his daily routine as a teacher, the students might have been confused about the switching role of the observer. Therefore, future research with a research design the other way around (first observing teachers then the students), or one which separates the operating order with two observers in the field, might clarify the identified principles. Finally, it should be noted that a follow-up interview was only conducted with the teacher (Mr. Hofstätter), in which the six principles were presented and discussed. Additional follow-up interviews with the students would have been helpful to confirm or supplement the extracted principles by all of the participants.

Despite these limitations, the present study has extended the existing research on the teacher-student relationship by using extensive data from a long and intense ethnographic field study. Qualitative methodology was used in this study to explore and promote a greater depth of understanding of the topic than might be achieved in a quantitative design. In particular the extensive breadth and depth of observation sequences allow insights into the dynamics of the teacher-student relationship from both teachers and students that, to our knowledge, have never 
been studied in such a detailed way before. Our findings provide important evidence that the teacher-student relationship is mainly restricted by implicit institutional roles, manifested in the principles of power, solidarity, dualism and productivity. Both teacher and students experience their relationship and educational settings as unsatisfactory, when reduced to their institutional roles. Schools should provide more room for teachers and students to develop a sustainable, human (being-level) and pedagogical (role-level) basis, to allow for a loose, constructive, and interactive cooperation, which includes the principles of sympathy and identity. Finally, effective and satisfying teaching and learning processes can only be accomplished if they are mutual.

A replication of these findings with a larger, more representative population (students from different school types, e.g., private, public) with different socio economic status (SES) in a longitudinal and cross-cultural quantitative study would add to the richness of our understanding of these issues. A quantitative design would also allow a detailed examination of aspects that were touched upon in the present study, such as motivation, interest and school well-being. Specifically, the use of a traingulative method that combines quantitative, experimental and qualitative methods (Raufelder, Jagenow, Hoferichter, \& Wilkinson, 2012) would be ideal for gathering data on the complex and dynamic character of the teacher-student relationship. More understanding of when and how the six principles of the teacher-student relationship emerge in students and teachers will help in the development of preventative programs which promote a positive teacher-student relationship and support effective learning and teaching processes, as well as healthy personal and professional development.

\section{References}

Alerby, E., \& Hertting, K. (2007). Reflections on the meaning of social relations between teachers and students. Paper presented at the meeting of the Australian Association for Research in Education (AARE) 37th Annual International Education Research Conference, Fremantle, Australia.

Atkinson, P., \& Hammersley, M. (1994). "Ethnography and Participant Observation". In N. Denzin \& Y. Lincoln (eds.), Handbook of Qualitative Research (pp. 248-161). Thousand Oaks, CA: Sage.

Bayerwaltes, M. (2002). Große Pause: Nachdenken über Schule. München, GER: Kunstmann.

Becker, H. S. (1996). The epistemology of educational research. In R. Jessor, A. Colby, \& R. Schweder (Eds.), Essays on ethnography and human development (pp. 53-71). Chicago, IL: University Press of Chicago.

Becker, H., \& Blanche, G. (1979). Teilnehmende Beobachtung: Die Analyse qualitativer Forschungsergebnisse. In C. Hopf \& E. Weingarten (Eds.) Qualitative Sozialforschung (pp. 139-166). Stuttgart, GER: Ernst Klett.

Becker, B. E., \& Luthar, S. S. (2002). Social-emotional factors affecting achievement out- comes among disadvantaged students: Closing the achievement gap. Educational Psychologist, 37, 197-214. http://dx.doi.org/10.1207/S15326985EP3704_1.

Birch, S. H., \& Ladd, G. W. (1996). Interpersonal relationships in the school environment and children's early school adjustment: The role of teachers and peers. In J. Juvonen, \& K. Wentzel (Eds.), Social motivation Understanding children's school adjustment (pp. 199-225). Cambridge: University Press.

Birch, S. H., \& Ladd, G. W. (1997). The teacher-child relationship and children's early school adjustment. Journal of School Psychology, 35, 61-79. http://dx.doi.org/10.1016/S0022-4405(96)00029-5.

Birch, S. H., \& Ladd, G.W. (1998). Children's interpersonal behaviors and the teacher-child relationship. Developmental Psychology, 34, 934-946. http://dx.doi.org/10.1037/0012-1649.34.5.934.

Braun, V. and Clarke, V. (2006) Using thematic analysis in psychology. Qualitative Research in Psychology, 3, 77-101. http://dx.doi.org/10.1191/1478088706qp063oa

Böhnisch, L. (1996). Pädagogische Soziologie: Eine Einführung. Weinheim, GER: Juventa.

Bohnsack, R. (1997). Adoleszens, Aktionismus und die Emergenz von Milieus: Eine Ethnographie von Hooligan-Gruppen und Rockbands. Zeitschrift für Sozialisationsforschung und Erziehungssoziologie, 1, $3-18$.

Bornhoff, A., \& Bornhoff, J. (2007). SOKO - ein Schultraining sozialer Kompetenzen und seine Auswirkungen auf die Lehrerbelastung und das Schulklima: Eine Untersuchung an Realschulen. University of Heidelberg. http://archiv.ub.uni-heidelberg.de/volltextserver/volltexte/2007/7792/ (accessed June 03, 2008).

Brendgen, M., Vitaro, F., Boivin, M., Girard, A., Bukowski, W. M., Dionne, G., Tremblay, R. E., \& Pérusse, D. (2009). Gene-environment interplay between peer rejection and depressive behavior in children. Journal of Child Psychology and Psychiatry, 50, 1009-1017. 
Brophy, J., \& Good, T. (1974). Teacher-student relationships: Causes and consequences. New York, NY: Holt, Rinehart \& Winston.

Bukowski, W. M, Laursen, B., \& Hoza, B. (2010). The snowball effect: Friendship moderates escalations in depressed affect among avoidant and excluded children. Development and Psychopathology, 22, 749-757. http://dx.doi.org/10.1017/s095457941000043x

Bukowski, W. M., Newcomb, A. F., \& Hartup, W. W. (1996). The company they keep: Friendship in childhood and adolescence. New York, NY: Cambridge University Press.

Crowley, J. E. (2007). Friend or Foe? Self-Expansion, Stigmatized Groups, and the Researcher-Participant Relationship. Journal of Contemporary Ethnography, 36, 603-630.

DeWalt, K. M., DeWalt, B. R., \& Wayland, C. B. (1998). Participant observation. In H. R. Bernard (Ed.), Handbook of methods in cultural anthropology (pp. 259-299). Walnut Creek, CA: AltaMira Press.

DeWalt, K. M., \& DeWalt, B. R. (2002). Participant observation: a guide for fieldworkers. Walnut Creek, CA: AltaMira Press.

Douglas, J. D. (1976). Investigative social research. Beverly Hills, CA: Sage.

Douglas, J. D., \& Johnson, J. M. (1977). Existential sociology. New York, NY: Cambridge University Press.

Dressman, M. (2006). Teacher, teach thyself: Teacher research as ethnographic practice. Ethnography, 7 , 329-356. http://dx.doi.org/10.1177/1466138106069524

Eccles, J., Wigfield, A., \& Schiefele, A. (1998). Motivation to succeed. In W. Damon, \& N. Eisenberg (Eds.), Handbook of child psychology (pp. 1017-1095). New York, NY: John Wiley \& Sons.

Emerson, R. M., Fretz, R. I., \& Shaw, L. L. (2001). Participant Observation and Fieldnotes. In P. Atkinson, A. Coffey, S. Delamont, J. Lofland, \& L. Lofland (Eds.), Handbook of Ethnography (pp. 356-357). Thousand Oaks, CA: Sage Publications.

Evans, C., \& Eder, D. (1993). "No exit": Processes of social isolation in the middle school. Journal of Contemporary Ethnography, 22, 139-170. http://dx.doi.org/10.1177/089124193022002001

Feiman-Nemser, S., \& Rémillard, J. (1996). Perspectives on learning to teach. In F. B. Murray (Ed.), The Teacher Educator's Handbook: building a knowledge base for the preparation of teachers (pp. 63-91). San Francisco, CA: Jossey-Bass.

Fend, H. (1997). Der Umgang mit Schule in der Adoleszenz. Aufbau und Verlust von Lernmotivation, Selbstachtung und Empathie. Bern, CH: Huber.

French, R. B. (1997). The teacher as container of anxiety: psychoanalysis and the role of teacher. Journal of Management Education, 21, 483-495.

Geertz, C. (1973). The Interpretation of Cultures. London, GB: Hutchinson \& Co.

Geertz, C. (1983). Dichte Beschreibung. Frankfurt a. M., GER: Suhrkamp.

Geertz, C. (1993). Local Knowledge. London, GB: Fontana Press.

Geertz, C. (2000). Available Light: Anthropological Reflections on Philosophical Topics. Princeton: University Press.

Gottlieb, G. (1997). Synthesizing nature-nurture: Prenatal roots of instinctive behavior. Mahwah, NJ: Erlbaum.

Hakanen, J., Bakker, A., \& Schaufeli, W. (2006). Burnout and work engagement among teachers. Journal of School Psychology, 43, 495-513. http://dx.doi.org/10.1016/j.jsp.2005.11.001

Hamre, B. K., \& Pianta, R. C. (2006). Student-teacher relationships as a source of support and risk in schools. In G. G. Bear, \& K. M. Minke (Eds.), Children's needs III: Development, prevention, and intervention (pp. 59-71). Bethesda, ML: National Association of School Psychologists.

Harrington, B. (2003). The social psychology of access in ethnographic research. Journal of Contemporary Ethnography, 32, 592-625. http://dx.doi.org/10.1177/0891241603255677

Harter, S. (1996). Teacher and classmate influences on scholastic motivation, self-esteem, and level of voice in adolescents. In J. Juvonen, \& K. Wentzel (Eds.), Social motivation - Understanding children's school adjustment (pp. 11-42). Cambridge: University Press.

Harter, S. (1999). The construction of the self: A developmental perspective. New York: Guilford Press. 
Hascher, T. (2007). Exploring students' well-being by taking a variety of looks into the classroom. Hellenic Journal of Psychology, 4, 331-349.

Haselbeck, F. (1999). Lebenswelt Schule. Passau, GER: Wissenschaftsverlag Richard Rothe.

Haselbeck, F. (2007). Schule - Bildungsinstitution und Lebensort: Theorie und Alltag der Schule. Aachen, GER: Shaker.

Hayer, T., Scheithauer, H., \& Petermann, F. (2005). Bullying: Schüler als Täter - Lehrer als Opfer?!. In A. Ittel \& M. von Salisch (Eds.), Lügen, Lästern, Leiden lassen - Aggressives Verhalten von Kindern und Jugendlichen (pp. 237-255). Stuttgart, GER: Kohlhammer.

Hinsch, R., \& Pfingsten, U. (2007). Das Gruppentraining sozialer Kompetenzen

(GSK). Grundlagen, Durchführung, Materialien. 5. Auflage. Weinheim, GER: PVU.

Hitzler, R., \& Honer, A. (1984). Lebenswelt - Milieu - Situation. Kölner Zeitschrift für Soziologie und Sozialpsychologie, 36, 56-74.

Hornstein, W. (1990). Aufwachsen in Widersprüchen: Jugendsituation und Schule heute. Stuttgart, GER: Klett.

Horstkemper, M. (2000). Geschlechtsidentität und unterrichtliches Handeln. In M. Schweer (Ed.), Lehrer-Schüler-Interaktion (pp. 139-158). Opladen, GER: Leske \& Budrich.

Howell, Joseph T. (1972). Hard Living on Clay Street: Portraits of Blue Collar Families. Prospect Heights, IL: Waveland Press.

$\mathrm{H} \ddot{u ̈ t h e r, ~ G . ~(2007) . ~ A t m o s p h a ̈ r e ~ s c h a f f e n ~ f u ̈ r ~ E n t w i c k l u n g ~-~ E r k e n n t n i s s e ~ u n d ~ K o n s e q u e n z e n ~ a u s ~ d e r ~}$ Hirnforschung. In Existenzanalyse. Retrieved September 07, 2012, from http://www.existenzanalyse.co.at/TEXTE/erkenntnishirn.html

Ittel, A., \& Raufelder, D. (2008). Lehrer und Schüler als Bildungspartner: Ansätze zwischen Tradition und Moderne. Göttingen, GER: Vandenhoeck \& Ruprecht.

Jennings, P. A., \& Greenberg, M. T. (2009). The prosocial classroom. Teacher social and emotional competence in relation to student and classroom outcomes. Review of Educational Research, 79, 491-525. http://dx.doi.org/10.3102/0034654308325693

Jensen, E. (1998). Teaching with the brain in the mind. Alexandria, VA: Association for Supervision and Curriculum Development.

Jensen, E. (2000). Brain-Based Learning: A Reality Check. Educational Leadership, 57, 76-80.

Klem, A. M., \& Connell, J. P. (2004). Relationships matter: linking teacher support to student engagement and achievement. Journal of School Health 74, 262-273. http://dx.doi.org/10.1111/j.1746-1561.2004.tb08283.x.

Krumm, V., \& Weiß, S. (2000). Ungerechte Lehrer: Zu einem Defizit in der Forschung über Gewalt an Schulen. Psychosozial, 23, 57-73.

Krüger, R. (1994). Das Lehrer-Schüler-Verhältnis. In L. Roth (Ed.), Pädagogik. Handbuch für Studium und Praxis (pp. 799-812). München, GER: Ehrenwirth.

Lerner, R. M. (1986). Concepts and theories of human development (2nd ed.). New York: Random House.

Lerner, R. M. (1991). Changing organism-context relations as the basic process of development: A developmental contextual perspective. Developmental Psychology, 27, 27-32. http://dx.doi.org/10.1037/0012-1649.27.1.27

Lerner, R. M. (1998). Theories of human development: Contemporary perspectives. In W. Damon (Series Ed. \& R. M. Lerner (Eds.), Handbook of child psychology: Vol. 1 (5th Ed.): Theoretical models of human development (pp. 1-24). New York, NY: John Wiley \& Sons.

Lewin, K., Lippit, R., \& White, R. K. (1939). Patterns of aggressive behavior in experimentally created social climates. Journal of Social Psychology, 10, 271-301.

Lincoln Y. S., \& Guba, E. G. (1985). Naturalistic inquiry. Beverly Hills, CA: Sage.

Lipka, R. P., \& Brinthaupt, T. M. (1999). The role of self in teacher development. Albany, NY: State. University of New York Press.

Lofland, J. (1995). Analytic Ethnography: Features, Failings, and Futures. Journal of Contemporary Ethnography, 24, 30-67. http://dx.doi.org/10.1177/089124195024001002 
Loser, G., \& Terhart, E. (1994). Schule als Lebensraum - Schüler und Lehrer. In L. Roth (Ed.), Pädagogik. Handbuch für Studium und Praxis (pp. 895-868). München, GER: Ehrenwirth.

Lubbers, M. J, Van Der Werff, M. P. C., Snijders, T. A. B., Creemers, B. P. M., \& Kuyper, H. (2006). The impact of peer relations on academic progress in junior high. Journal of School Psychology, 44, 491-512. http://dx.doi.org/10.1016/j.jsp.2006.07.005

Marshall, C., \& Rossman, G. B. (1995). Designing qualitative research. Newbury Park, CA: Sage.

Morse J. M. (1995). The significance of saturation. Qualitative Health Research, 5, 147-149. http://dx.doi.org/10.1177/104973239500500201

Nickel, H. (1981). Die Transaktionalität der Lehrer-Schüler-Beziehung und ihre Bedeutung für die Unterrichtspraxis. In A. Weber (Ed.), Lehrerhandeln und Unterrichtmethode (pp. 27-48). München, GER: Wilhelm Fink.

Nickel, H. (1993). Die Lehrer-Schüler-Beziehung als transaktionaler Prozeß. In H. Nickel (Ed.), Psychologie der Entwicklung und Erziehung (pp. 244-261). Pfaffenweiler: Centaurus.

Nohl, H. (1933/1957). Die pädagogische Bewegung in Deutschland und ihre Theorie. Frankfurt a.M., GER: Schulte-Bulmke.

Patten, K. (2004). Neuropaedagogy: Imagining the Learning Brain as Emotive Mind. Vancouver: Paper Presented at IERG Conference.

Pianta, R. C., Hamre, B. K., \& Stuhlman, M. W. (2003). Relationships between teachers and children. In W. M. Reynolds, \& G. E. Miller (Eds.), Educational psychology. Comprehensive handbook of psychology, 7. (pp. 199-234). New York, NY: Wiley.

Pianta, R. C., \& Nimitz, S. L. (1991). Relationships between children and teachers: Associations with classroom and home behavior. Journal of Developmental Psychology, 12, 379-393. http://dx.doi.org/10.1016/0193-3973(91)90007-Q

Raufelder, D. (2007). Von Machtspielen zu Symapthiegesten. Marburg, GER: Tectum.

Raufelder, D., Jagenow, D., Drury, K., \& Hoferichter, F. (2013). Social relationships and motivation in secondary school: Four different motivation types. Learning and Individual Differences, 24, 89-95. http://dx.doi.org/10.1016/j.lindif.2012.12.002

Raufelder, D., Jagenow, D., Hoferichter, F., \& Wilkinson, R. P. (2012). An interdisciplinary challenge: method triangulation in the field of brain development and motivation. Psychology Research, 2, 627-636.

Raufelder, D., \& Mohr, S. (2011). Zur Bedeutung sozio-emotionaler Faktoren im Kontext Schule unter Berücksichtigung neurowissenschaftlicher Aspekte. In A. Ittel, H. Merkens, L. Stecher, \& J. Zinnecker (Eds.), Jahrbuch Jugendforschung (pp. 74-96). Wiesbaden: VS.

Ria, L., C. Sève, J. Saury, J. Theureau, \& Durand, M. (2003). Beginning Teachers' Situated Emotions: a study of firts classroom experiences. Journal of Education for Teaching, 29, 219-233. http://dx.doi.org/10.1080/0260747032000120114

Roth, L. (1994). Forschungsmethoden der Erziehungswissenschaft. In L. Roth (Ed.), Pädagogik. Handbuch für Studium und Praxis (pp. 32-67). München, GER: Ehrenwirth.

Rudow, B. (1999). Stress und burnout in the teaching profession: European studies, issues, and research perspectives. In R. Vandenberghe and M. A. Huberman (Eds.), Understanding and preventing teacher burnout: A sourcebook of international research and practice (pp. 38-58). Cambridge, GB: Cambridge University Press.

Schaarschmidt, U. (2005). Halbtagsjobber? Psychische Gesundheit im Lehrerberuf - Analyse eines veränderungsbedürftigen Zustandes. Weinheim, GER: Beltz.

Schwartz, S., \& Green-Schwartz, C. (1955). Problems in participant observation. American Journal of Sociology, 60, 343-353. http://dx.doi.org/10.1086/221566

Smith, J. A., \& Osborn, M. (2003) Interpretative phenomenological analysis. In J.A. Smith (Ed.), Qualitative Psychology: A Practical Guide to Methods (pp.51-80). London, GB: Sage.

Stipek, D. J. (2004). Teaching practices in kindergarten and first grade: Different strokes for different folks. Early Childhood Research Quarterly, 19, 548-568. 
Tausch, R., \& Tausch, A.-M. (1991). Erziehungspsychologie. Göttingen, GER: Hogrefe.

Taylor S. J., \& Bogdan R. (1984). Introduction to qualitative research methods: the search for meanings. New York, NY: John Wiley and Sons.

The American Heritage ${ }^{\circledR}$ Dictionary of the English Language. (2000). Boston, MA: Houghton Mifflin Company.

Travers, C. J., \& Cooper, C. L. (1996). Teachers under stress. Stress in the teaching profession. London, GB: Routledge.

Vieno, A., Santinello, M., Pastore, M., \& Perkins, D. D. (2007). Social support, sense of community in school, and self-efficacy as resources during early adolescence: An integrative, developmentally oriented model. American Journal of Community Psychology, 39, 177-190.

Watt, H. M. G. (2004). Development of adolescents' self perceptions, values and task perceptions according to gender and domain in 7th through 11th grade Australian students. Child Development, 75, 1556-1574. http://dx.doi.org/10.1111/j.1467- 8624.2004.00757.x.

Weber, M. (1921/1980). Wirtschaft und Gesellschaft. Grundriß der verstehenden Soziologie. Tübingen, GER: J.C.B. Mohr.

Wentzel, K. R., Battle, A., Russell, S. L., \& Looney, L. B. (2010). Social supports from teachers and peers as predictors of academic and social motivation. Contemporary Educational Psychology, 35, 193-202. http://dx.doi.org/10.1016/j.cedpsych.2010.03.002.

Wentzel, K. R. (2009). Students' relationships with teachers as motivational contexts. In K. R. Wentzel, \& A. Wigfield (Eds.), Handbook of motivation at school (pp. 301-322). New York, NY: Routledge.

Zusho, A., \& Pintrich, P. R. (2001). Motivation in the second decade of life. In T. Urdan, \& F. Pajares (Eds.), Adolescence and education (pp. 163-200). Greenwich, CT: Information Age Publishing.

\section{(c)) EY}

This work is licensed under a Creative Commons Attribution 3.0 License. 